\title{
Stage IIIA Testicular Cancer AJCC v8
}

National Cancer Institute

\section{Source}

National Cancer Institute. Stage IIIA Testicular Cancer A/CC v8. NCI Thesaurus. Code C140238.

Stage IIIA includes: (Any pT /TX, Any N, M1a, S0); (Any pT /TX, Any N, M1a, S1). TX:

Testicular cancer in which the primary tumor cannot be assessed. M1a: Testicular cancer with non-retroperitoneal nodal or pulmonary metastases. S0: Marker study levels within normal limits. S1: LDH less than $1.5 \times \mathrm{N}$ and $\mathrm{hCG}(\mathrm{mlU} / \mathrm{mL})$ less than 5,000 and AFP $(\mathrm{ng} / \mathrm{mL}$ ) less than 1,000. $\mathrm{N}$ indicates the upper limit of normal for the LDH assay. (AJCC 8th ed.) 